\title{
Apocalyptic Trends in Contemporary Politics
}

Recibido: 25 de setiembre de 2017

Stella Marega

University of Trieste, Italia stella.marega@live.com

Aceptado: 20 de noviembre de 2017

\begin{abstract}
:
The symbol of apocalypse contains strong political connotations linked to eschatological expectations: the faith in a divine intervention on the course of history has often generated social instability, outbreaks of violence, and ideological claims.

This article aims to demonstrate as the overlap between apocalyptic symbolism and political phenomena is still ongoing, even assuming new critical implications in connection with recent geopolitical dynamics on a global scale.

The detection of the apocalyptic trends is supported by a historical premise, a brief summary of theoretical perspectives, and three study cases: the presence of messianic aspects in US imperialism, the influence of the doctrine of the Hidden Imam in the Iranian politics during the Ahmadinejad presidency, and the use of apocalyptic prophecies in the Islamic State's propaganda. ${ }^{1}$
\end{abstract}

\section{Keywords:}

Apocalypse, Politics, Political Religions, Political Symbolism, Eschatology, Messianism

\section{Resumen:}

El símbolo del apocalipsis contiene fuertes connotaciones políticas vinculadas a expectativas escatológicas: la fe en una intervención divina en el curso de la historia a

\footnotetext{
1 The paper was presented at the First Doctoral Conference in Religious Studies "Enchantments, Disenchantments, Re-enchantments: Religion, State, and Society through History", at the Center for Religious Studies of the Central European University, Budapest, June $29^{\text {th }}$-July $1^{\text {st }} 2017$; it resumes and develops my previous work: Marega S., (December, 2016) II regno della fine dei tempi: una premessa miticosimbolica all'analisi delle politiche apocalittiche.Heliopolis. Culture, Civiltà, Politica, XIV, vol. 2, pp. 147-161.
} 
menudo ha generado inestabilidad social, brotes de violencia y reivindicaciones ideológicas.

Este ensayo pretende demostrar que la superposición entre el simbolismo apocalíptico y los fenómenos políticos está todavía en curso, incluso asumiendo nuevas implicaciones críticas en relación con las recientes dinámicas geopolíticas a escala mundial.

La detección de las tendencias apocalípticas se basa en una premisa histórica, un breve compendio de las perspectivas teóricas y tres casos de estudio: la presencia de aspectos mesiánicos en el imperialismo estadounidense, la influencia de la doctrina del Imam Oculto en la política iraní durante la presidencia de Ahmadinejad y el uso de profecías apocalípticas en la propaganda del Estado Islámico

\section{Palabras clave:}

Apocalipsis, Política, Religiones políticas, Simbolismo político, Escatología, Mesianismo

\section{Tendencias apocalípticas en la política contemporánea}

\section{Introduction}

The debate about the role of religion in modern political societies has taken an everincreasing importance in the last decades. In recent times the thesis of secularization as a character of modernity, unreservedly accepted far from the Enlightenment, has proven to be at least inadequate, facing the existence of religious dynamics that often have significant political implications, and political claims with evident religious foundations (Norris, Inglehart, 2004, pp. 3-32).

The worldwide occurrence of terroristic attacks, wars of religion, the intensification of fundamentalisms, the new rise of nationalism and xenophobia, have put social scientists forehead to the need to investigate the revival of religious beliefs as a phenomenon of deep urgency and topicality. Among the various aspects worthy of being analyzed, it is legitimate to focus deeply on the role of apocalyptic symbolism and its exploitation by political actors: the hypothesis is that it has a persisting - and mostly underestimated influence on the contemporary political conjuncture. 
Over the course of the twentieth century, many studies have already highlighted the existence of a mythical-symbolic complex bound to eschatological expectations, that stems from Jewish and Christian apocalypticism and continue into modern times, decisively affecting the political course of modern Western history. The classical case studies focus on the reception of millennialist themes by the movements of the Middle Ages and Reformation, as well as by the advocates of great Revolutions of the Late Eighteenth Century. Equally well-known are the studies that investigated the eschatological implications of the National Socialist, Positivist and Communist ideology.

Particularly influential was the thesis developed by the German scholar Eric Voegelin in The Political Religions (1938) and later in The New Science of Politics (1952). Voegelin identified a path of secularization of the apocalyptic expectations, began with the transfer of the Christian theology of history in the immanent sphere and culminating in the construction of modern totalitarian regimes: an assumption subsequently taken over by many scholars. Voegelin's theory contemplates, on the one hand, a process of secularization, which accompanies the devaluation of the sacred contents of the apocalyptic symbol; on the other hand, a movement in the opposite direction, coinciding with the re-divinization of the world, through the attribution of religious contents to secular phenomena, such as politics.

Taking into account the acquisitions shared by the scientific community, and updating them according to the most recent data, this research aims at identifying the main apocalyptic trends operating in the contemporary politics.

The first part of the essay focuses on the origins of political apocalypticism in the Abrahamic religions and illustrates the processes of symbolic transference of the eschatological beliefs in Western history. The second part exposes three study cases (USA, Iran, and Islamic State) highlighting three major tendencies: the assignment of an eschatological destiny to political subjects, the attribution of messianic features to the figures of charismatic leaders, and use of apocalyptic symbols and prophecies in the political propaganda.

La Revista Estudios es editada por la Universidad de Costa Rica y se distribuye bajo una Licencia Creative Commons Atribución-NoComercial-CompartirIgual 3.0 Costa Rica. Para más información envíe un mensaje a revistaestudios.eeg@ucr.ac.cr. 


\section{General characters}

\subsection{Political features of Apocalypse in Abrahamic religions}

The Greek term "apokalypsis" namely means "unveiling" or "revelation". The word was used to identify the last book of the New Testament, containing the divine revelation about the "things that are going to happen", received from John of Patmos and formulated as a letter to the Seven Churches of Asia Minor. The Revelation of John warns that "the time is near" and exhorts the believers to endure the tribulations and to keep the faith until God's intervention will be accomplished. The divine will is gradually revealed at the opening of the Seven Seals in an escalation of catastrophic signs, appearances of angelic and monstrous figures, and finally comes to the chaining of Satan who will be thrown into the Abyss where he will remain for a thousand years; only then shall the heavenly Jerusalem descend from heaven and become the glorious abode of God and his people.

Although the term "apocalypse" has Greek origins and is rooted in the Christian environment, various characters of the apocalyptic thought are pre-existent to the term itself, and witnessed since the Neolithic cultures, in connection with the cults of death and the beliefs about the cyclical destruction and regeneration of the world (De Martino, 1977).

The core of apocalyptic thought assumes its political connotations only within Abrahamic religions, when the catastrophic end of the world is transferred in an imminent moment and starts being defined as a divine decision over the course of history. Despite an univocal definition has not yet been shared by all scholars, the nucleus of apocalyptic thought can be resumed in the idea of a "divinely-determined-sense of history" and the model of "crisisjudgment-vindication for the coming End" (McGinn, 1984, pp. 10-11).

The apocalyptic tendencies within Judaism began to develop at the time of Persian domination. During this period, through contacts with Greek and Oriental cultures, and mostly with Zoroastrianism, new theological elements were introduced into ancient Judaism: in particular the dualistic criterion of the contrast between good and evil (which 
implies an ethical choice) and the belief in the judgment of souls after death. The acceptance of these principles constituted the premise for the development of the Western apocalyptic thought (McGinn, 1984, p. 10).

In 538 BC the edict of Cyrus II ended the Babylonian captivity, and the Jews were allowed to return to Jerusalem and rebuild the destroyed Temple. The first messianic expectations linked to the dream of a monarchic restoration converged on the figure of Zerubbabel, leader of the Jews in their exodus from Babylon to Judea and, according to the prophecies, descendant of King David from a royal ancestry (Rose, 2000). The final passage from prophecy to apocalyptic took place some centuries later, during the socalled inter-testamentary period: ever since, the political dimension in biblical literature became more and more evident (Charles, 1945).

In the Book of Daniel, composed around 164 BC but set in the era of Babylonian domination, it was described the enigmatic dream of the king Nebuchadnezzar: the destruction of an enormous statue - made of gold, silver, bronze, iron and clay symbolizing the collapse of the Empires. The interpretation of the vision prophesied the rise and fall of the great kingdoms of antiquity: Babylon, the Persian kingdom of Cyrus the Great, the Macedonian kingdom of Alexander the Great, and the last, the strongest and powerful, destined to be divide but never to disappear altogether. Several interpreters identified the fourth empire in the Seleucid kingdom of Antiochus IV, which governed Judea at the time of writing the Book of Daniel; most of the Christian exegetes, instead, attributed the text to a different value, seeing in the fourth kingdom the Roman Empire (Grabbe, 2001, pp. 229-246).

In the following centuries, the myth of Rome became part of the millennial expectations with ever greater strength. In the Revelation of John, Rome is portrayed as the Babylonian prostitute, the incarnation of the vices and wickedness of the worldly kingdoms and opposed to the holy city of Jerusalem, the image of the Kingdom of God and the symbolic centre of the renewal of the world. Even in the visions of the subsequent Jewish apocalypses of Esdra and Baruch, Rome is destined to be annihilated before the 
establishment of the divine Kingdom of justice and peace (Esdra, 11:43-12:3; 2 Baruch, 36-40). It is interesting to notice that, if in Judaism the announcement of the Kingdom was historically linked to a national context, in Christianity emerged an eschatology ecumenical-oriented, ending up by linking the apocalypse with the imperialist claims of Rome.

In turn, even the Roman Empire was creating its own political myth, assuming a salvific mission in the incarnation of the katechon, the only power capable of retaining the advent of the Antichrist, preventing the disintegration of chaos and the triumph of the saeculum (Paul, Thess. 2, 6-7).

The expectations set for the establishment of the imperium sine fine have been consolidated by some fragments of the Sibylline Oracles and by Latin poets such as Horace and Virgil, who had announced the advent of a glorious kingdom that would unite the peoples of the world under a universal law. The myth of Rome was also supported by the sacralization of the figure of the Emperor, seen from time to time as "Savior of the human race", "Keeper of eternal life", "Bearer of everlasting light” (García-Pelayo, 1980, p. 74). Subsequently, to the figure of the Emperor, overlapped/opposed the figure of Jesus Christ, Rex, Imperator, Pantocrator, sovereign of heaven and earth, principle and image of universal royalty (Peterson, 1951, pp. 151-164).

Thus, in the first centuries, the apocalyptic idea of the final reign took on a double nuance: the religious-messianic one, bound to the expectation in the return of Jesus Christ, and the political-imperialist one, linked to the power of Rome. These two nuances did not really fail to overlap and confuse, making the complex relationship between apocalyptic expectancies and worldly power never exhausted.

In the development of the apocalyptic myth of the last empire, it was highly relevant the contribution of the Calabrian Abbot Joachim of Fiore. The diffusion of his theological doctrine, as well as transferring the expectation for the third and last era of humankind in an imminent time, in fact, gave also a new force to the messianic figure of the Dux, 
conveying the apocalyptic expectations over Francis of Assisi and Federico II. It was, in particular, the latter to incarnate the medieval idea of the empire as an instrument of divine providence: even after his death, his myth continued to proliferate: the prophecies saw him defeat the Antichrist in the final battle and deposit the imperial insignia on the Golgotha, returning them to Christ, the only legitimate possessor (García-Pelayo, 1980, pp. 79-80). The figure of the Emperor, thus, fulfilled the eschatological task of leading his people towards a new time and a new world.

Similar issues also occur in Islamic eschatology. In the Qur'an are described the countless signs that predict the coming of the end times, the cataclysms that will fall on earth on the day of judgment, and the resurrection of the souls destined to the Paradise. However, it is not in the Qur'an, but in some hadith (literally a "new thing", the word indicates a story, anecdote, or saying about Muhammad's life and word, handed down by the Companions of the Prophet) and in other sacred texts, that is given more relevance to the appearance of a series of messianic figures related to the final events: Al-Masih ad-Dajjal, the false Messiah or Antichrist, the Mahdi, in some traditions identified with the figure of the Last Imam, and Issa, the Prophet Jesus. The figure of the Mahdi is central in Islamic apocalyptic theories, being the one that takes on the messianic expectations regarding the last era of the world (Kalaji, 2008, 34-36).

The two main currents of Islamism have a different attitude towards the figure of the Mahdi: the Sunnis believe it must still be born, while the Shiites associate the belief in the Mahdi with the doctrine of the Occultation and believe that the Mahdi is already present on the Earth, living hidden in the expectation of being revealed. Most Shiites also belong to the current of the Duodecimans or "Twelvers", the disciples of the twelve Imams, and identify the Mahdi with the Twelfth or Last Imam (Cook, 2002, pp. 189-229). Despite the figure of the Twelfth Imam possessing a highly spiritual character, the belief in its coming has assumed a strong political connotation: this expectation deprives legitimacy of any existing worldly government, reducing it to a temporary substitute for the true holder of universal power, and charging the present moment of a strong apocalyptic tension. 
From this short summary, it should be clear that the apocalyptic characters present within monotheistic religions are various: they include not only a specific literature genre defined as "apocalyptic", but also expectancies about the end times connected with political positions. Among them, the most significant are: the expectation of a final subversion determined by divine intervention in history, the expectations of the establishment of an imperial kingdom (often connected with the symbolic power of Rome), the expectations for the return of a messianic figure with the characters of the leader.

\subsection{Apocalyptic Symbolism and Western History: Interpretative Lines}

The transference of the apocalyptic expectations from their original religious context into the secular world is a process long, complex and impossible to summarize. However, it is possible to point out some of the most meaningful interpretive lines which, until now, allowed affording the analysis of this topic.

One of the best-known interpretations of the political nature and the social effects of the apocalyptic symbolism is the one proposed by Eric Voegelin. Voegelin's theory on apocalypse is rather complex, and has developed into successive phases throughout his career: here, therefore, we will consider some excerpts, related to the first phase of his intellectual path, which had the major influence on subsequent studies about the relationship between religion and politics.

In the 1938s essay The Political Religions, aimed at investigating the historical causes that led to the rise of National Socialism, a brief chapter is devoted precisely to the symbolism of the apocalypse. It focuses, in particular, on the role of Joachim of Fiore's historical doctrine in the secularization of the religious symbolism of history. According to Voegelin, Joachim's innovation with respect to his forerunners (Paul and Augustine) did not consist in the subdivision of history in three eras (the Realm of the Father, the Realm of the Son, the Realm of the Holy Ghost), but in considering the Third Realm as a forthcoming immanent reality. With the reception of Joachim's theology of history, in other words, the 
symbol of the apocalypse, which, until then, had been perceived as the end of the earthly world and the beginning of the Kingdom of Heaven, was transfigured in the expectation of a revolutionary event that would have begun a new era on this earth.

Voegelin came back several times on the subject, identifying both a precise set of symbols originated in Joachim's doctrine and resumed in modern ideologies (the Dux, the Prophet, the Leaders and the Ecclesia or the Community of believers), and a series of attitudes that characterize the "modern Gnostics", the promoters of the secular "apocalyptic revolution".

Similar considerations on the nature of the philosophy of history as a process of secularization of eschatological beliefs were elaborated around the 1930s both by Jacob Taubes and Karl Löwith. A few years before, various historians had recognized the connection between the apocalyptic movements of the Middle Ages and the revolutionary tension of the modern ideologies, not without exaggerating the scope of their intuitions and the role of Joachim of Fiore within the subversive tendencies.

In 1957, Norman Cohn published a very influential book titled The Pursuit of the Millennium: once again, an attempt to interpret the totalitarian ideologies of the 20th century in light of the apocalyptic tension inherited from the European Middle Ages. Cohn emphasized, among other things, the importance of the expectation in the final battle and the belief in the coming of the messianic kingdom of Jesus Christ in the evolution of the ideologies of history. The analogies between the various populist movements triggered by the chiliastic eschatology of Middle Ages and the totalitarian movements of XX century are found in the common aspiration to subvert the established order of the world, in an attempt to change its structure.

The Italian scholar Luciano Pellicani further developed these themes in his works I rivoluzionari di professione (1974) and La società dei giusti (1995), where he states that modern millennialism constitutes "the most extraordinary and disruptive historical-cultural phenomenon of the age of secularization", since "it has replaced transcendence with the

La Revista Estudios es editada por la Universidad de Costa Rica y se distribuye bajo una Licencia Creative Commons Atribución-NoComercial-CompartirIgual 3.0 Costa Rica. Para más información envíe un mensaje a revistaestudios.eeg@ucr.ac.cr.
} 
complete immanence and the Paradise with a class-less and state-less society" (Pellicani, 1995, p. I).

Although the list of such studies is not exhaustive, it is worth also mentioning, because of its relevance, the work of Barry Cooper, New Political Religions, or an Analysis of Modern Terrorism (2004), where he exploits Voegelin's assumptions for the interpretation of terrorist phenomena such as Aum-Shinrikyo and Al-Quaeda.

Within the research developed on this trail, the work of the Catalan jurist Manuel García Pelayo on political myth is rather effectual in the analysis of the political apocalypticism. According to Pelayo, the idea of the apocalypse could be considered a development of the myth of the "the kingdom of the end time", a concept so widespread to constitute a common substrate in all cultures.

The myth of "the kingdom of the end time" is defined as a model that sets a present time felt as a condition of insecurity and injustice, in which solution will be given in one of two alternative ways:

1- A miraculous final event which will establish a kingdom of peace and justice.

2- A final fight against the forces of evil where the forces of good (justice, truth ...) are meant to prevail.

In the first case, therefore, there will be a supernatural intervention: this is the religious form of myth. In the second case, we have, instead, the secularized version of the myth, for which the transformation will take place regardless of the involvement of a supernatural force (García-Pelayo, 1980, p. 67).

In both cases, the final kingdom owns three main features:

1- It will be established "at the end of times", after a catastrophic event or a final fight.

2- In the final struggle there will be a leader, identified with the Savior, or in other versions, with the Last Emperor.

3 - The final kingdom will have an ecumenical character, as it will involve all people of the earth (García-Pelayo, 1980, pp. 67-68). 
In the following part of this article, it will be examined how this myth, or some of its part, still works nowadays.

\section{Study Cases}

\subsection{The Final Kingdom: the USA Case}

The first apocalyptic trend that will be examined is the manifestation of the idea of the end time kingdom. This type of political myth is common to all political entities that have expressed imperialist ambitions throughout history. As we have seen, the idea of empire is intrinsically linked to the idea of apocalypse, as it implicates:

- the manifestation of a divine will;

- the fulfillment of a decisive/final event in history;

- the expression of a universal and "ecumenical" power.

In the Western world, there is some reticence in the use of the term "empire" in reference to contemporary political entities, at least since the collapse of the Soviet Union. Nowadays, the very idea of empire brings with it a strongly negative meaning, opposed to the principles of democracy and national sovereignty.

Among the studies dealing with imperialist symbolism, could be useful to mention the contribution of Le religioni della politica, by the Italian scholar Emilio Gentile, which echoes - beyond the title - several assumptions already expressed by Voegelin. The introduction, in particular, takes up a famous debate raised by Robert Bellah in 1967 about the United States civil religion. The most interesting insights concern the definition of the US civil religion as a form of sacralization of politics and the detection of the religious symbols transferred in the political dimension.

In the political myth on which the United States ground their identity, all the religious clichés can be find: the Sacred Scriptures (The Declaration of Independence and the 
Constitution), the Prophets (Pilgrim Fathers), the Messiah (George Washington), the Martyrs (Abraham Lincoln, John Fitzgerald Kennedy), the sacred places (Washington Monument, Lincoln Memorial, Arlington National Cemetery), the sermons, the liturgies, and the sacred days (Gentile, 2007, p. VI).

According to Gentile, the civil religion of the United States constitutes a form of sacralization of politics very different from the ancient forms of sacralization of political power and from the modern (totalitarian) political religions. Its main indicators are:

1 - the independence of the political dimension from the religious one;

2 - the character of sacredness assumed by the political dimension;

3 - the prerogative of defining the meaning of human existence claimed by politics;

4 - the dependence of the fate of individuals and the community from the subordination to a supreme entity;

5 - the self-attribution by the State of an apocalyptic mission: the nation is considered elected by God to pursue a saving mandate for the benefit of all mankind. (Gentile, 2007, pp. VI).

In the last point, the use of apocalyptic symbology by the United States is clearly revealed, so that the argument does not need any other explanation.

The issue of US imperialism has become relevant in recent decades with regard to foreign policy undertaken by the United States, becoming an act of accusation especially after the Gulf War of 2003: whether at the time of the Vietnam War, or the intervention in the Persian Gulf, the critical positions against the United States were limited to disagreement with its governmental actions, after the invasion of Iraq the feeling of disapproval became an anti-imperialist impetus, which awakened epochal questions about the nature of power and imperial sovereignty (Münkler, 2008, p. vii). In spite of a subsequent overturn by Obama's policy and the bitter awareness of new economic limits, the US case shows that the messianic myth of the universal empire, advocating defence against chaos and tyranny, has never ceased to exist. 


\subsection{Messianic Expectations: the Iran Case}

The second apocalyptic trend that will be taken in consideration is constituted by the presence, within contemporary politics, of eschatological expectancies aimed at the return of a messianic figure.

The theme obviously lends itself to many declinations, so much so that it could be applied successfully to almost all political leaders. Indeed, to a different extent, to the representatives of the various political formations are often attributed (or self-attributed) the characters of the messianic warlord, destined to lead the people to a symbolic revolution and to a promised "new world".

I would like to mention here a specific case in which apocalyptic connotations have taken on particular implications: the faith in the return of the Hidden Imam, came into force with a strong political connotation a few years ago in Iran, during the presidency of Mahmoud Ahmadinejad.

The source for this insight is the essay Apocalyptic Politics. On the Rationality of Iranian Policy, where Mehdi Kalaji offers an important contribution to the analysis of Islamic Messianic tendencies, highlighting the dynamics developed in Iran after the failure of the 1979 Iranian Revolution. The abandonment of the project of a theocratic empire governed by Islamic law was followed by an authoritarian turning point and by a revival of eschatological beliefs related to hope in the return of the Last Imam, a path that led "from utopianism to apocalypticism" (Kalaji, 2008, p. IX).

The phenomenon, singularly, was not promoted by Khomeini's successor, Alì Khamenei: the Supreme Leader, while supporting the belief in the doctrine of Hidden Imam, never made the Mahdi the centrepiece of his public discourse, and never made it clear that the return of the Mahdi would be considered imminent. The apocalyptic prophecy, 
substantially, remained a marginal aspect of religion, which never assumed revolutionary shades and never influenced significantly the daily lives of believers (Kalaji, 2008, p. 3).

The President Mahmoud Ahmadinejad, on the contrary, while pursuing a political-religious line distant and less conservative than that of Khamenei, played the major role in the emergence of apocalyptic tendencies. Ahmadinejad is recognized as a controversial figure, known for his populist politics aimed at the redistribution of wealth but also for his anti-Zionist and anti-American positions. International concern over his presidency was also raised by his support to the nuclear program.

Ahmadinejad's presidency has been marked, since its inception, by the faith in the imminent return of the Mahdi: the political reach of this belief, always present in his public talks, is substantial. The wait for the Mahdi causes a dramatic vortex of instability, as present time is perceived as a chaotic moment, and is filled with revolutionary expectations. In addition, this expectation is also reflected in the devaluation of the role of religious actors, since every religious guide (including the Supreme Leader) should be considered only as a temporary replacement of the Last Imam.

Kalaji also points out how Ahmadinejad exploited the belief in the Mahdi to support rivalry against Israel: the expectation of the last Imam had been brought to a "countdown for the fall of Zionist regime". Another example of "an arbitrary use of apocalyptic traditions for political purposes" (Kalaji, 2008, p. 36).

The most controversial issue is the one related to the nuclear program. Ahmadinejad relied on various institutes and academies that promoted a new scientific course for Iran. One of the crucial points is precisely the vital role that these organizations attribute to technology to foster the expected return of Imam and the question if the nuclear program could be included in this project. Clearly, there is no tradition attesting this belief: "Shiite apocalyptic literature explicitly says that the only human action that can speed up the Hidden Imam's reappearance is payer and obedience" (Kalaji, 2008, p. 38).

Kalaji's analysis reveals that Khamenei's religious doctrine has not reached Ahmadinejad's apocalyptic drifts for a variety of reasons: the distance from revolutionary and imperialist 
ideologies, the dialogue with various power groups, and, ultimately, the refusal to fulfill "his dreams ambitions at the price of chaos" (Kalaji, 2008, p. VIII-IX). Chaos, indeed, is the necessary condition for the re-appearance of the Last Imam.

These considerations offer a significant contribution to the comprehension and the study of the relationship between apocalyptic tendencies and contemporary politics, demonstrating, once again, that the emergence of apocalyptic trends is intrinsically connected with the themes of messianic expectations and imperialist dominion.

\subsection{Apocalyptic Prophecies: the Islamic State Case}

The third and last apocalyptic trend that will be examined concerns the explicit use of apocalyptic prophecies in political propaganda: the instance here considered is the case of the self-proclaimed Caliphate or Islamic State, also known by the acronyms ISIS, ISIL or DAESH.

Despite, after the President Trump's election and the new worldly political turmoil, the attention of the media toward the geopolitical dynamics in Middle West is slightly faded, the Islamic State continue to keep attention on itself, mostly through - and due to unceasing episodes of terrorist attacks worldwide. It's fair to assert that the understanding of the apocalyptic ideology within the Islamic State vision, is crucial to the understanding of his operating strategies.

The issue has been highlighted in 2014, thanks to an online article by William McCants: ISIS Fantasies of an Apocalyptic Showdown in Northern Syria, later developed in the volume The ISIS Apocalypse. The History, Strategy, and Doomsday Vision of the Islamic State (2015). McCants observed how the presence of apocalyptic elements within the ideological structure of the Caliphate was absolutely predominant. His intuition was then repeated in many respects from the media around the world. 
In the article of 2014, in particular, McCants referred to the apocalyptic fantasies connected with the city of Dabiq, in the north of Syria, a theatre, according to a hadith by Abu Hurairah, of the last battle against the Romans. The episode is a Malahim: an equivalent of the Christian Apocalypse or the Jewish Armageddon. The city of Dabiq plays a symbolic role since it had already been the scene of a historic battle of the Mamluk soldiers against the Ottoman Empire in 1516. According to the prophecy, the defeat of the Romans at Dabiq would be followed by the approximation of the end of times, with the conquest of Constantinople, the defeat of the Antichrist, and finally the return of the prophet Jesus.

The importance of Dabiq's prophecy has come to light not only with the city's conquest in August 2014 but, above all, with the choice of the name as a manifesto of the Islamic State propaganda. "Dabiq" was, in fact, the name of the online magazine that, since July 2014 till July 2016, spread the voice and mission of the Islamic State, also working as a tool for jihadist recruitment worldwide and attempt to legitimize the State and its structures.

Each issue of the magazine brings in the quotation of Dabiq's prophecy in the version pronounced by the first jihadist leader Abu Musab al-Zarqawi:

"The spark has been lit here in Iraq, and its heat will continue to intensify - by Allah permission - until it burns the crusader armies in Dabiq".

A slogan and a statement of intent. The quote is also accompanied by its explanation: "According to the hadith, the area will play a historical role in the battles leading up to the conquests of Constantinople, then Rome."

The publication of Dabiq endured until the fifteenth issue, on July 2016. After the Islamic State was expelled from the territory of Dabiq by the Free Syrian Army, indeed, the magazine was replaced with a new publication. The header of the new journal, Rumiyah, refers to another apocalyptic prophecy concerning the conquest of Rome, the symbol of the universal power and the incarnation of the imperialist ambitions. Rome, already

\footnotetext{
(c) (i)(3)

La Revista Estudios es editada por la Universidad de Costa Rica y se distribuye bajo una Licencia Creative Commons Atribución-NoComercial-CompartirIgual 3.0 Costa Rica. Para más información envíe un mensaje a revistaestudios.eeg@ucr.ac.cr.
} 
mentioned in the previous issues of Dabiq, represents the apocalyptic opponent, which should be overwhelmed and defeated in order to obtain the final, everlasting supremacy.

The front cover of the first issue of Rumiyah opens with a quote from Abu Hamzah alMuhajir, the precursor of the Islamic State:

"O muwahhidin, rejoice, for by Allah, we will not rest from our jihad except beneath the olive trees of Rumiyah (Rome)."

The back page of the same issue, under a full illustration of an olive tree, features a hadith which reminds again the enduring power of Rome, destined to be destroyed last:

"Allah's Messenger (Muhammad) was asked, "Which of the two cities will be conquered first? Constantinople or Rumiyah?» He (Muhammad) replied, "The city of Heraclius will be conquered first» meaning Constantinople."

The back page of the tenth issue of Rumiyah, dedicated to the jihad in East Asia and to the Ramadan, comes back to the final struggle against the apocalyptic figure of al-Dajjal, the deceiver:

"Imran Ibn Husayn narrated that Allah's Messenger (Muhammad) said, There will no cease to be a group from my ummah fighting upon the truth, manifest over those who oppose them until the last of them fights al-Masih ad-Dajjal'

The apocalyptic prophecies regarding the final battle and the conquest of Rome, besides their eschatological content, reveal also the imperialist ambition implied in the yearned restoration of the Caliphate. It should not be forgotten, moreover, that, as the Caliph is Mohammed's temporary vicar, the establishment of his government implies not only the theological legitimacy of the political power but also the claim of a universal representation in respect to the community of Islamic believers.

\section{c) (1) (9)}

La Revista Estudios es editada por la Universidad de Costa Rica y se distribuye bajo una Licencia Creative Commons Atribución-NoComercial-CompartirIgual 3.0 Costa Rica. Para más información envíe un mensaje a revistaestudios.eeg@ucr.ac.cr. 


\section{Conclusions}

To summarize what has been since here noted, apocalyptic trends are detectable in the following cases:

1 - politics that takes advantage of the idea of the ultimate realm of peace and justice, ecumenical, total, destined to reign over all the nations of the world. The establishment of this kingdom is pursued with all available means (economy, communication, technology, war, etc.).

2 - politics that exploit the expectation for the return of a messianic figure with the characters of the Savior or of the Emperor of the final times, which can be a spiritual guide or a political or religious leader, to whom is attributed a role of universal command.

3 - politics that manifestly use apocalyptic prophecies by including them in their goals and propaganda.

The results of this inquiry, far from exhaustive, can be resumed in two statements. First, the analysis of religious symbols is an unavoidable mean in the attempt to understanding political dynamics. Second, the influence of apocalyptic thought is still ongoing in the contemporary world and has a strong influence on political actions and military operations.

Definitely, since it is impossible to completely isolate the religious sphere from that political, it is desirable at least to recognize the dangerous drifts of this relationship. According to many scholars who dealt with this topic - and to the present state of facts - it is legitimate to observe that the attempt to exploit the apocalyptic tension in politics is destined to a tragic outcome: war and oppression are the only ascertained results of the project of men who, feeling entrusted with a divine mission, search for a "perfect ending", that, fortunately, has not yet arrived. 


\section{Bibliography}

Charles, R. H. (1945). Religious Development between the Old and New Testament. Oxford: Oxford University Press.

Cook, D. (2005). Contemporary Muslim Apocalyptic Literature. Syracuse, N.Y.: Syracuse University Press.

De Martino, E. (1977; 2002). La fine del mondo. Contributo all'analisi delle apocalissi culturali. Torino: Einaudi.

García- Pelayo, M. (1980). Los mitos políticos. Madrid: Alianza Universidad.

Gentile, E. (2007). Le religioni della politica. Fra democrazie e totalitarismi. RomaBari: Editori Laterza.

Grabbe, L. L. (2001). A Dan[iel] for all Seasons: For Whom was Daniel Important? In Collins, J. J.; Flint P. V. (edited by) The Book of Daniel: Composition and Reception, Vol. 1, Boston-Leiden: Brill Academic Publishers, pp. 229-246.

Khalaji, M. (2008). Apocalyptic Politics: On the Rationality of Iranian Policy. Washington: The Washington Institute for Near East Policy.

McCants, W. (2015). The ISIS Apocalypse: The History, Strategy, and Doomsday Vision of the Islamic State. New York: Palgrave Macmillan.

McGinn, B (1984). Early Apocalypticism: the Ongoing Debate. In C. A. Patrides C. A., J. A. Wittreich, A. (edited by) The Apocalypse in English Renaissance Thought and Literature: Patterns, Antecedents, and Repercussions, Manchester: Manchester University Press, pp. 2-39.

\section{(c) (1) (2)}

La Revista Estudios es editada por la Universidad de Costa Rica y se distribuye bajo una Licencia Creative Commons Atribución-NoComercial-CompartirIgual 3.0 Costa Rica. Para más información envíe un mensaje a revistaestudios.eeg@ucr.ac.cr. 
Münkler, H. (2007). The Logic of World Domination from Ancient Rome to the United States. Cambridge: Polity Press.

Norris, P. Inglehart, R. (2004). Sacred and Secular. Religion and Politics Worldwide. Cambridge: Cambridge University Press.

Pellicani L. (1995). La società dei giusti. Parabola storica dello gnosticismo rivoluzionario. Milano: Etas Libri.

Peterson, E. (1936). "Christus als Imperator”. In: Id., (1951) Theologische Traktate, Münich: Kösel-Verlag.

Rose, W. H. (2000). Zemah and Zerubbabel: Messianic Expectations in the Early Postexilic Period. Sheffield: Sheffield Academic Press.

Voegelin, E. (1938). The Political Religions. In: Id., (2000) Modernity without Restraint, Collected Works vol. 5. Columbia and London: University of Missouri Press.

Voegelin, E. (1952). The New Science of Politics. In: Id., (2000). Modernity without Restraint, Collected Works vol. 5. Columbia and London: University of Missouri Press.

\section{Web references}

Clarion Project (Dabiq - Rumiyah Issues) https://clarionproject.org/islamic-state-isis-isil-propaganda-magazine-dabiq-50/

McCants W., "ISIS Fantasies of an Apocalyptic Showdown in Northern Syria" http://www.brookings.edu/blogs/iran-at-saban/posts/2014/10/03-isis-apocalypticshowdown-syria-mccants 